


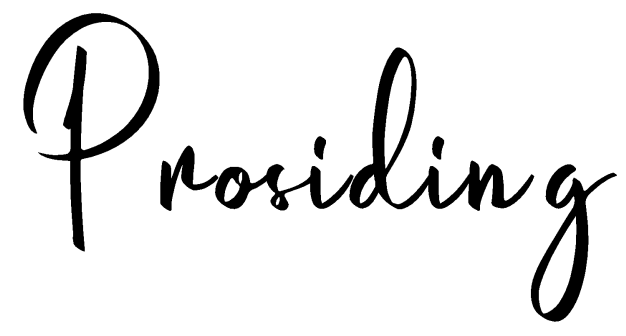

\section{LOKAKARYA INTERNASIONAL \\ DAN PELATIHAN METODOLOGI PENELITIAN \\ ISLAM NUSANTARA}

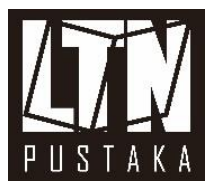




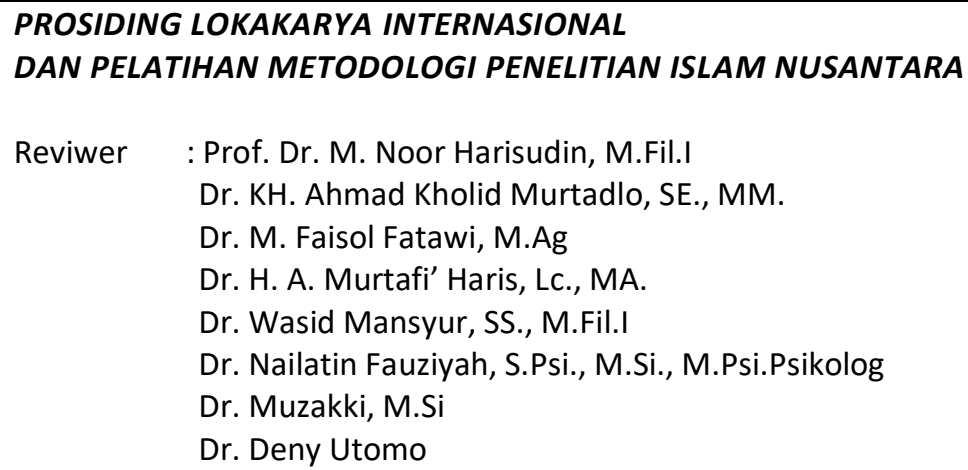

Editor : Chafid Wahyudi, S.Th.I., M.Fil.I

H. Ahmad Karomi, M.Th.I

Dr. Winarto Eka Wahyudi, M.Pd.I

Ahmad Miftahul Haqq, M.Pd

Muhammad Nur Hadi, S.Ag., M.Pd.I

M. Said Hudaini Kadmi, S.Fil., MA.

Mukani, M.Pdl

Lia Hilyatul Masrifah, M.Si

H. Ifdlolul Maghfur, M.E.I

Ahmad Hanan, S.Kom

Desain : Tim Kreatif LTN NU Jawa Timur

Tata letak : Tim Kreatif LTN NU Jawa Timur

Diterbitkan oleh:

PW LTN NU Jawa Timur/LTN Pustaka

Jl Masjid Al Akbar Tim No.9, Gayungan

Surabaya, Jawa Timur, 60235

Cetakan pertama, Oktober 2019

xiii $+350 \mathrm{hlm} ; 15,5 \mathrm{~cm} \times 23 \mathrm{~cm}$

ISBN: $978-623-90022-3-7$

Hak cipta @ All Right Reserved

Hak cipta dilindungi undang-undang. Hak moral dimiliki oleh penulis. Hak ekonomi dimiliki oleh penulis dan penerbit berdasarkan perjanjian. Dilarang mengutip atau memperbanyak dalam bentuk apapun tanpa izin tertulis dari penulis dan penerbit. 


\section{Sambutan Ketua PW LTN NU Jawa Timur}

Assalamualaikum $W r, W b$.

Alhamdulillah wa syukru lillah, tiada kata yang pantas untuk diucapkan selain puji syukur kehadirat Allah subhanahu wa ta'ala, Sang Maha Penggegam Langit dan Bumi. Serta, tiada lupa shalawat serta salam kepada junjungan Nabi Besar Muhammad shallallahu 'alaihi wasallam beserta keluarga, para sahabat, dan seluruh ummatnya yang senantiasa istiqomah hingga akhir zaman.

Bermula ketika para masyayikh Nahdlatul Ulama memerintahkan kami di kepengurusan LTN NU Jawa Timur untuk melaksanakan program pendidikan literasi, kami merancang beberapa program unggulan berkaitan dengan tema-tema Islam dan kepesantrenan. Salah satunya, kami beri nama program Pelatihan Metodologi Penelitian Islam Nusantara dan Pendidikan Kader Muallif. Program yang pertama, sejak munculnya diskursus Islam Nusantara pasca Muktamar ke-33 di Jombang hingga tahun 2019 sudah 3 (tiga) kali angkatan. Angkatan pertama kami selenggarakan di Pondok Pesantren Alif Lam Mim Surabaya yang diasuh oleh Dr. KH. Ahmad Imam Mawardi, MA., yang kedua diselenggarakan di IAIN Jember, dan yang ketiga diselenggarakan di Universitas Yudharta Pasuruan. Makalah dari para peserta pada angkatan ketiga inilah yang kemudian menjadi buku prosiding ini. Adapun program yang kedua baru dimulai pada tahun 2019 dengan angkatan pertama yang diselenggarakan di Pondok Pesantren An-Nur II Al-Murtadlo Bululawang Kabupaten Malang. 
Program Lokakarya dan Pelatihan Metodologi Penelitian Islam Nusantara ke-3 ini sesungguhnya bermaksud untuk (1) merumuskan arah pengembangan kajian Islam Nusantara pada tataran akademis-ilmiah; (2) membangun kesadaran literasi Islam Nusantara berbasis pada manuskrip; (3) membangun jaringan peneliti-penulis yang concern pada kajian Islam Nusantara; dan (4) mengkonsolidir para intelektual untuk membuat gerakan bersama dalam membendung Islam radikal melalui spirit literasi Islam Nusantara.

Dengan demikian, yang kami harapkan dengan program ini adalah, adanya cetak biru (blue print) pengembangan kajian Islam Nusantara yang dapat dijadikan rujukan oleh para peneliti yang ingin mendalami kajian Islam Nusantara, di tengah polemik dan pandangan pro-kontra yang muncul pasca Muktamar ke-33 Nahdlatul Ulama di Jombang Jawa Timur tanggal 1-5 Agustus 2015. Selain itu, harapan lainnya, para peserta yang mengikuti program ini memiliki kesadaran literasi Islam Nusantara yang kuat yang memiliki jaringan kuat dan solid. Pengembangan kajian Islam Nusantara secara akademik ini penting untuk terus dilakukan sebagai upaya menggali khazanah ilmu pengetahuan Islam di tanah air.

Akhirnya, dengan terbitnya buku prosiding ini, PW LTN NU Jawa Timur menyampaikan apresiasi setinggi-tingginya kepada para peserta yang telah mengajukan artikelnya sebagai materi diskusi, juga kepada panitia yang telah bekerja keras menyelenggarakan kegiatan hingga terbitnya prosiding ini. Semoga prosiding ini dapat memberikan kemanfaatan bagi kita semua.

Surabaya - Pasuruan, 19 November 2019

H. Ahmad Najib AR., M.Th.I 


\section{Sambutan Ketua Umum ASPIRASI}

Meski dikritik sebagian orang, kajian Islam Nusantara masih eksis hingga sekarang. Karena umumnya kritik yang disodorkan pada wacana Islam Nusantara lebih dilatari oleh nuansa kebencian, subjektif dan sehingga tidak akademis. Di sisi lain kita melihat, kajian akademis Islam Nusantara selalu menarik, laris manis dan bahkan terus booming.

Buktinya, ada banyak buku, jurnal ilmiah, baik skala internasional yang terus bermunculan dengan tema Islam Nusantara. Bahkan kajian lebih spesifik misalnya Fiqh Nusantara, Dakwah Islam Nusantara, Tarekat Nusantara, Ijtihad Islam Nusantara, dan sebagainya. Ini semua menunjukkan bahwa kajian Islam Nusantara menjadi tema yang eksotik dan menarik banyak kalangan.

Seperti terlihat dalam "The $3^{\text {rd }}$ International Worshop and Training on Islam Nusantara Research Metodology", yang diselenggarakan oleh Asosiasi Penulis dan Peneliti Islam Nusantara Seluruh Indonesia, PW Lembaga Ta'lif wa an-Nasyr NU Jawa Timur dan Universitas Yudharta Pasuruan pada 27-28 September 2019. Bertempat di Universitas Yudharta Pasuruan Jawa Timur, Pelatihan Islam Nusantara yang ketiga ini sangat istimewa karena selain dihadiri para sarjana dari banyak tempat di Indonesia, juga utusan dari PCI-NU Mesir, PCI-NU Belanda dan PCI-NU Malaysia. 
Salah satu hal yang membedakan dengan pelatihan sebelumnya adalah adanya call paper dalam "The $3^{\text {rd }}$ International Worshop and Training on Islam Nusantara Research Metodology" kali ini. Setelah melakukan presentasi dan diskusi tentang call paper, makalah selanjutnya diberi masukan dan catatan kritik para reviewer sehingga menjadi tulisan yang lebih analitis, utuh, dan komprehensip. Prosiding yang ada di hadapan pembaca ini adalah produk kongkrit dari "The $3^{\text {rd }}$ International Worshop and Training on Islam Nusantara Research Metodology" tersebut.

Selaku Ketua Umum ASPIRASI, saya mengucapkan terima kasih yang setinggi-tingginya pada narasumber: Prof. KH. Said Agil Siradj, MA (Ketum PBNU), KH. Marzuki Mustamar (Ketua PWNU Jawa Timur), Prof. Dr. H. Oman Fathurrahman, MA (Guru Besar UIN Syarif Hidayatullah Jakarta), Prof. KH. Nadirsyah Hosen, MA(Hons)., L.LM., Ph.D (Monash University, Australia), Associate Profesor Azhar Ibrahim Alwee, Ph.D (National University of Singapore), Dr. H. Muhammad Zein, MA (Kepala Pusat Balitbang Kemenag RI), Dr. Mahrus el-Mawa, M. Si (Kasi Penelitian Kemenag RI), Dr. Zainul Milal Bizawie (Islam Nusantara Center Jakarta), H. A. Ginanjar Sya'ban, Lc, MA (Islam Nusantara Center Jakarta) dan Dr. M. Faishal Fatawi, MAg (UIN Maulana Malik Ibrahim Malang).

Terima kasih pada segenap peserta yang telah berpartisipasi dalam lokakarya tersebut. Terima kasih juga saya sampaikan pada panitia yang telah lelah dan berjibaku menyelenggarakan acara ini, khususnya pada Sdr. Chafid Wahyudi (Ketua Panitia) dan Sdr. Abdur Rahim (Sekretaris Panitia). Demikian juga tim penyunting naskah sehingga naskah menjadi naskah yang lebih baik.

Saya ucapkan terima kasih yang sebesar-besarnya teutama pada Ketua Pengurus Wilayah Lembaga Ta'lif wa an-Nasyr NU 
Jawa Timur, KH Najib AR, Juga pada Pengasuh Pondok Ngalah, KH Sholeh, saya ucapkan sebesar-besarnya. Termasuk Dr. Kholid, M.Pd.I Rektor Universitas Yudharta, terima kasih atas semuanya.

Akhirnya, selamat membaca!

Jember, 10 Oktober 2019

Prof. Dr. M. Noor Harisudin, M. Fil. I 


\section{Sambutan Rektor Universitas Yudharta Pasuruan}

Puji dan syukur kehadirat Allah Subhanahu wa Ta'ala, Tuhan Yang Maha Kuasa yang terus mencurahkan rahmat dan karuniaNya kepada kita semua, serta dengan ridlo-Nya hingga acara the $3^{R D}$ International Workshop and Training on Islam Nusantara Research Methodology dan Call for Papers dapat terlaksana dengan baik dan Prosiding ini dapat diterbitkan. Kegiatan ini diselenggarakan atas kerjasama Universitas Yudharta Pasuruan dengan Lembaga Ta'lif wan Nasyr Pengurus Wilayah Nahdlatul Ulama (LTN PWNU) Jawa Timur yang dibuka oleh Prof. Dr. KH. Said Aqil Siroj, MA., Ketua Umum Pengurus Besar Nahdlatul Ulama (PBNU).

Kegiatan yang digelar selama 3 hari pada 25-27 ${ }^{\mathrm{TH}}$ September 2019 ini terdiri dari beberapa rangkaian agenda acara, yakni: 1) Lokakarya Internasional, 2) Pelatihan Metodologi Islam Nusantara, 3) Madrasah Jurnalistik, 4) Pameran Manuskrip Islam Nusantara, dan 5) Bursa Buku Islam Nusantara. Kami mengapresiasi yang setinggi-tingginya atas suksesnya penyelenggaraan kegiatan yang progresif dalam rangka membahas secara komprehensif untuk mewujudkan generasi intelektual Nahdliyyin yang lebih kompetitif. Dari acara ini Dosen, Mahasiswa, dan para intelektual Nahdliyyin telah banyak menghasilkan penelitian-penelitian tentang Islam Nusantara sebagai bagian dari progress dan implementasi al 
Muhafadlotu 'Ala al Qodiimis Shalih wa al Ahdlu bi al Jadidil Ashlah, bukan hanya sekedar melestarikan nilai-nilai Islam Ahlussunnah wa al Jama'ah pada radius teritorial Nusantara saja, melainkan juga dalam rangka mengembangkannya sesuai dengan perkembagangan zaman.

Dengan demikian, the $3^{R D}$ International Workshop and Training on Islam Nusantara Research Methodology ini menjadi ajang bagi Dosen, Mahasiswa, dan para intelektual kader Nahdliyyin di manca negara untuk mempresentasikan hasil penelitiannya sekaligus discussion dalam rangka memperdalam case study masing-masing, serta mengembangkan kerjasama dibidang penelitian dan publikasi ilmiah yang sustainable. Akhirnya, dengan adanya kerjasama yang baik ini semoga dapat memberikan manfaat dan barokah bagi para generasi Nahdliyyin baik yang ada di Indonesia maupun di manca negara. Amin.

Pasuruan, 8 Oktober 2019

Dr. H. Ahmad Kholid Murtadlo, SE., ME. 


\section{Daftair 7si}

Sambutan Ketua LTN NU Jawa Timur ～| iv

Sambutan Ketua Umum ASPIRASI | vi

Sambutan Rektor Universitas Yudharta Pasuruan ～| ix

Daftar Isi | $\quad$ xi

\section{Manuskrip Kesatu}

KARISMA PEMIKIRAN DAKWAH PESANTREN NUSANTARA

$\checkmark$ Dakwah Nusantara: Etika Dai dalam Zad Al-Zu'ama wa Dhakhirat Al-Khutaba' Karya KH. Bisri Mustofa

Mohammad Ikhwanuddin \& Darmawan । 1

$\checkmark$ Setrategi Dakwah KH. M. Sholeh Bahrudin dalam

Mengembangkan Sikap Toleransi

M. Jamhuri । 24

$\checkmark$ KH. M. Ma'shum Ali, Tradisi Literasi dan Karya Monumental Yang Mendunia

Mukani \& Jumari $\quad$ | 40

$\checkmark$ Politik Praktis Kiai NU di Kabupaten Pasuruan

Miftachul Taubah \& Muhammad Nur Hadi । 53

$\checkmark$ Inklusivisme Moqsith Ghazali: Konsep Soteriologi Muhammad Lutfi \& Miatul Qudsia । 63

$\checkmark$ Legalitas Tipologi Dakwah Wali Songo Perspektif Al-Qawa'id AlFiqhiyah

Miftaqurrohman | 77

$\checkmark$ Pemikiran Syuhudi Ismail dalam Memahami Hadis

Amir Mahmud \& Mukhid Masyhuri । 111

$\checkmark$ KH. M. Qoyim Ya'qub; Internalisasi Nilai-Nilai Al-Qur'an Melalui Syair dan Nada

Qurrotul Ainiyah \& Dita Dzata Mirrota । 123

$\checkmark$ Kiai dan Akar Resolusi Konflik Berkarakter Islam Nusantara Ahmad Wiyono । 137 
$\checkmark$ Abdurrahman Wahid, Sang Dinamisator Pesantren Slamet Untung \& Ahmad Ubaedi Fathudin । $\mathbf{1 4 4}$

$\checkmark$ Warisan Intelektual Nurcholish Madjid Tentang Modernisasi Pendidikan Pesantren

Siti Yumnah | 167

$\checkmark$ Pemikiran Kiai Said Aqil Siroj Tentang Ahl Al- Sunnah Wa AlJama'ah

Budi Harianto \& Nurul Syalafiyah ～～ $\mathbf{1 8 4}$

$\checkmark$ Strategi Dakwah KH. Ali Masud dalam Menyebarkan Syiar Islam di Sidoarjo

Milla Ahmadia Apologia \& Nur Azzah Fathin $\quad \mid 199$

$\checkmark$ Strategi Dakwah KH. Abdul Ghofur dalam Melestarikan Islam Nusantara

Ali Ahmad Badawi Syamsuri | $\mathbf{2 1 2}$

$\checkmark$ Rekayasa Sosial Dakwah Islam Nusantara

Totok Agus Suryanto । 224

\section{Manuskrip Kedua}

NUSANTARA DAN TEKS KEISLAMAN

$\checkmark$ Eksistensi Kitab Kuning: Kultur Santri Lintas Generasi Ulil Izzah ～～ 239

$\checkmark$ Hikayat Karya Syekh Rasul sebagai Mediasi Penyebaran Islam bagi Masyarakat Karduluk Sumenep

Iftitah | 252

$\checkmark$ Potret Islam Nusantara: Sebuah Kajian Korpus Nur Inda Jazilah ～～ 263

$\checkmark$ Tradisi Sanad dan Revitalisasi Keilmuan Pesantren Muhammad Bisyri | 278

$\checkmark$ Pesantren Nusantara: Internalisasi Nilai-Nilai Multikultural di Pesantren Ngalah Pasuruan Achmad Yusuf \& Mochamad Hasyim 293 
$\checkmark$ Kritik Terhadap Pemikiran Al-Thufy dalam Menyikapi Kontradiksi Maslahat dan Teks

Muhammad Taufiq | $\mathbf{3 2 0}$

$\checkmark$ Nadzam Nahwu Jawa: Naskah Klasik Karya Ulama' Trenggalek Afrizal El Adzim Syahputra 332

$\checkmark$ Pendidikan Islam Perspektif Islam Nusantara Sauqi Futaqi

342

$\checkmark$ Intertekstualitas Budaya Islam [Jawa] Nusantara dalam Manuskrip Singir [Kajian Naskah Pesantren] Robby Zidni Ilman ZF

359

\section{Manuskrip Ketiga}

\section{SEJARAH SOSIAL DAN CAGAR BUDAYA ISLAM LOKAL}

$\checkmark$ Konsep Kesuburan Pada Menara Masjid Kudus: Sebuah Kajian Budaya

Nila Iliyyatuz Zulfa \& Siti Nuronia | 377

$\checkmark$ Keberagamaan Minoritas Muslim Suku Tengger, antara Eklektisisme dan Puritanisme Ahmad Marzuki I $\mathbf{3 8 7}$

$\checkmark$ Model Wisata Religi Masjid Cheng Hoo Pandaan debagai Katalisator Eskplanasi Nilai- Nilai Kebudayaan Islam di Pasuruan

Dina Uswatun Hasanah \& Ahmad Ma'ruf

401

$\checkmark$ Relasi Islam Nusantara dan Budaya Jawa Nur Wahdatul Chilmy E Ahmad Fauzi I $4 \mathbf{4 1 8}$

$\checkmark$ Dinamika Islam dan Kepercayaan Lokal dalam Pembentukan Ajaran Sangkan Paran dan Manunggal Abdulloh Hanif । $\mathbf{4 2 9}$

$\checkmark$ Komodifikasi Kesenian Islam, Tari Bedana Tradisional di Bandar Lampung Agus Mahfudin Setiawan ～| 444 
$\checkmark$ Pergumulan Hukum Islam dan Adat Osing: Identitas, Harmonisasi dan Kekhasan Islam Nusantara Moh. Lutfi Nurcahyono \& Hamam | 458

$\checkmark$ Menjaga Indigenous Santri: Potret Keberlanjutan Tradisi Santri Mustakim | 473

$\checkmark$ Local Genius Warisan Budaya Islam Nusantara sebagai Identitas Budaya dan Moderasi Islam di Indonesia: Tinjauan Arkeologis Imam Mash'ud

487

$\checkmark$ Kebudayaan Lokal sebagai Infrastruktur dan Konstruksi dalam Menduniakan Islam Nusantara

Sifaul Amin I 502

\section{Manuskrip Keempat}

\section{LITERASI PESANTREN: STRATEGI DAN PENGALAMAN}

$\checkmark$ Strategi Moderasi Pondok Pesantren Salafiyah Syafi'iyah Provinsi Gorontalo dalam Meneguhkan Harmoni Sosial di Indonesia Angga Teguh Prastyo | $\mathbf{5 1 8}$

$\checkmark$ Peran Guru Pendidikan Agama Islam dalam Menanamkan Sikap Toleransi Antar Umat Beragama di Sekolah

Muhammad Mahfud E Aslikhah । 537

$\checkmark$ Pembentukan Karakter Santri Peduli Lingkungan Melalui Tradisi Roan di Pesantren

Wahyu Syafa'at | 553

$\checkmark$ Kerukunan Masyarakat antar Umat Beragama di Kabupaten Banyuwangi

Amirotun Nahdliyah | 558

$\checkmark$ Literasi Digital Santri Milenial: Strategi Dakwah di Dunia Maya, Studi Kasus AIS Nusantara

Abdulloh Hamid \& Santi Andriyani । 568

$\checkmark$ Mendekatkan Literasi Tasawuf Pada Masyarakat Madura Zainol Hasan \& Atiqullah । 582 
$\checkmark$ Transformasi Strategis Holding Pesantren Menuju Kemandirian Ekonomi Pasca Disahkannya Ruu Pesantren: Perspektif Stakeholder Theory Abdillah Ubaid | $\mathbf{5 5 9}$

$\checkmark$ Implementasi Nilai-Nilai Ahlussunnah Wal Jama'ah (Aswaja) Pada Anak Usia Dini Muhammad Syaikhon I $\mathbf{5 7 1}$

$\checkmark$ Implementasi Literasi Melalui Metode Sorogan Al-Qur'an di Pondok Pesantren

Nur Arofah Tis'ina $\quad$ | $\mathbf{5 8 1}$

$\checkmark$ Implementasi Multikultural d Pondok Pesantren Ngalah Wachyuni । 589

Metode Bandongan dan Wetonan: Bentuk Pelestarian Tradisi Pengajian Tafsir Al-Jalalain di Pondok Pesantren Muhammad Fashihuddin | 601

$\checkmark$ Ragam Perspektif Elit Agama Islam Kabupaten Pasuruan dan Tantangan Ukhuwwah Wathaniyyah Makhfud Syawaludin | $\mathbf{6 1 3}$

$\checkmark$ Studi Kurikulum Perguruan Tinggi Berbasis Pondok Pesantren Siti Nur Indah Rofiqoh, Alimin, \& Sumardi । 627

$\checkmark$ Transformasi Moderasi Kepemimpinan Kyai dalam Pesantren: Konstruksi Spirit Peradaban Islam Nusantara Moh Fadli, Mustafa Lutfi, E Rizky Febrian Supriyadi ～| 641

$\checkmark$ Tauhid Sosial: Konstelasi Pemikiran Tauhid Mukhtar Ambai Kerinci dan Implikasinyaterhadap Tujuan Pendidikan Islam Muhamad Yusuf । 658

$\checkmark$ Eksistensi Pesantren Salaf dalam Menghadapi Revolusi Pendidikan 4.0

Muhammad Ilyas E Jasuli | 673

Sosiologi Pendidikan Perspektif Islam Nusantara di Daerah Pegunungan Kendeng Nganjuk

Wawan Herry Setyawan, Kristanti Yuntoro Putri, $\mathcal{E}$ Mukani I 686 
$\checkmark$ Pendidikan Pondok Pesantren Gabungan Antara Klasik dan Modern

Karyoto | 698

$\checkmark$ Ibu dan Pendidikan: Proses Pembentukan Karakter Multikultural Anak Berbasis Nilai-Nilai Budaya Lokal Askhabul Kirom | 706

$\checkmark$ Modernisasi Pendidikan di Pondok Pesantren Miftahul Mubtadiin Krempyang Tanjunganom Nganjuk Muhammad Ali Anwar | $\mathbf{7 1 8}$

$\checkmark$ Tantangan Pesantren salam Pemberdayaan Penyandang Cacat di Indonesia Aidan Mujtahidan | 739

$\checkmark$ Pegon Sebagai Kekuatan Literasi Tulis Islam Nusantara Refki Rusyadi | 754 


\title{
PENDIDIKAN ISLAM PERSPEKTIF ISLAM NUSANTARA
}

\author{
- Sanqi Futaqi -
}

ABSTRAK: | Perkembangan Pendidikan Islam di Nusantara tidak bisa dilepaskan dari perkembangan Islam Nusantara. Dalam dinamika historisnya, perkembangan Islam Nusantara juga sangat mewarnai orientasi dan corak pendidikan Islam yang dijalankan. Tulisan ini bertujuan untuk melakukan konseptualisasi

Artikel masuk: $\quad$ pendidikan Islam dalam perspektif Islam Nusantara agar tidak kehilangan ruh

24 September 2019 kenusantaraanya di tengah tantangan global bagi dunia pendidikan. Kajian ini akan membahas tiga hal, yakni 1) persentuhan antara pendidikan Islam dengan perkembangan Islam Nusantara; 2) orientasi pendidikan Islam yang bertumpu pada orientasi ilahiyah, orientasi insaniyah, dan orientasi alamiyah; 3) corak pendidikan yang memperlihatkan 4 (empat) corak yang menonjol (integratif, menekankan karakter, berwawasan multikultural, dan sufistik).

Kata Kunci: Pendidikan Islam, Islam Nusantara, Orientasi Pendidikan, Corak Pendidikan

\section{Pendahuluan}

Wacana Islam Nusantara semakin popular dalam kajian Islam di Indonesia. Wacana ini juga semakin banyak didiskusikan di beberapa forum ilmiah. Ketertarikan terhadap kajian ini tidak hanya soal kebaruan, melainkan juga karena dianggap sebagai satu tipologi keislaman yang tidak hanya relevan dengan konteks keindonesiaan, tetapi juga menawarkan jawaban atas berbagai permasalahan keagamaan baik di tingkat lokal maupun global. Bahkan, beberapa Negara tertarik untuk mengangkat Islam nusantara sebagai tema penting dalam forum-forum internasional.

Gagasan ini menarik didiskusikan lebih panjang lagi dengan berbagai diskusi mengenai bagaimana penerjemahan Islam dalam lanskap keagamaan umat Islam, baik secara institusional maupun kultural. Secara institusional, salah satu yang perlu didiskusikan adalah soal pendidikan Islam di nusantara mengingat islam hadir juga turut membawa misi edukatif (pendidikan), yaitu melahirkan 
generasi penerus melalui pembelajaran-pembelajaran mulai dari bentuknya yang sangat sederhana sampai pada pelembagaan professional seperti saat ini. Artinya, Islam Nusantara mengandung konsekuensi logis berkembangnya pendidikan Islam dengan corak dan tipologi yang khas nusantara.

Pertanyaannya kemudian, jika Islam Nusantara membawa dampak epistemologis pendidikan Islam di Nusantara, bagaimana persinggungan pendidikan Islam dengan pendidikan yang ada di Negara-negara liberal, terutama yang dibawa oleh Kolonial Belanda?. Pertanyaan ini melibatkan kajian sejarah bagaimana formulasi pendidikan Islam saat ini mengadopsi pendidikan Liberal yang ada di Barat. Ini berkaitan dengan pengaruh sistem persekolahan yang dibawa Belanda seiring dengan berkembangnya wacana Liberal di dunia Barat. Namun, dalam persinggungan ini, ada satu fenomena menarik bahwa pendidikan Islam - dalam kontak budaya pada saat itu - tidak sepenuhnya menerima konsep pendidikan liberal. Ada beberapa catatan kritis, dan bahkan penolakan terhadap sistem penddikan liberal. Faktanya, meski Belanda memegang kekuasaan pemerintahan, banyak komunitas pendidikan Islam, terutama pesantren, tetap mempertahankan nilai-nilai pendidikan seperti yang diajarkan oleh para ulama pendahulu penyebar agama Islam.

Bersamaan dengan dinamika sejarah persinggungan pendidikan Islam dengan sisem penddikan modern - lebih tepat sistem persekolahan, pendidikan Islam rupanya tetap menampilkan keunikan tersendiri. Pertama, pendidikan Islam lebih memainkan peran sebagai "regenerasi ulama" ketimbang melahirkan tenaga profesional seiring perkembangan pembagian kerja dalam sistem modern. Kedua, pendidikan Islam di Nusantara tidak sepenuhnya mengadopsi pola pendidikan dimana Islam pertamakali hadir di Arab, melainkan mencoba menjalin hubungan secara harmonis dengan kebudayaan masyarakat Nusantara. Ini bisa dilihat dari pelembagaan pendidikan Islam, seperti surau, pesantren, majlis ta'lim, dan lainnya, yang kesemuanya memuat pesan kultural masyarakat Nusantara, baik dari segi materi, metode, dan media pembelajaran. Ketiga, di tengah menguatnya pengaruh sistem 
pendidikan liberal di Barat, pendidikan Islam di bumi nusantara tidak semata-mata menjadikannya sebagai sistem pendidikan yang baru, namun menjadikanya sebagai sumber pendukung dengan tetap kokoh pada nilai-nilai keislaman dan kenusantaraan. Tentu saja, prosentase besar kecilnya pengaruh bergantung pada sistem pendidikan Islam yang mana, mengingat perbedaan kelembagaan yang ada. Di tambah lagi, keberadaan pesantren masih menampilkan tipologi yang beragam, karena umumnya kecenderungan disiplin Kiai sangat menentukan corak pendidikan pesantren yang diasuhnya.

Berdasarkan dari pembacaan tersebut, kiranya sangat penting menghadirkan konsep pendidikan Islam dengan karakter kenusantaraan yang khas, sebagai sebuah tawaran konseptual terhadap perkembangan masyarakat saat ini. Ini merupakan konsekuensi logis dari peran pentingnya pendidikan sebagai wadah regenerasi masyarakat.

\section{Konsep Islam Nusantara}

Sejak Islam Nusantara dikemukakan, istilah ini melahirkan berbagai penerjemahan yang beragam. Banyak kalangan merespon secara positif, dan juga sebagian kecil yang merespon sebaliknya. Respon negatif umumnya datang dari kelompok keagamaan yang kurang memahaminya secara komprehensif. Akibatnya, ia terlalu mudah menaruh curiga. Bahkan, menyebut Islam Nusantara sebagai ajaran yang menyesatkan. Biasanya kelompok ini memiki corak pemikiran Islam yang cenderung hitam-putih, kaku, dan ekslusif. Alih-alih mempelajarinya secara mendalam, ia lebih dulu menaruh curiga dan menuduh di luar kemampuan yang dimilikinya.

Menampik tuduhan yang tidak berdasar tersebut, perlu kiranya dikemukakan terminologi komprehensif mengenai Islam Nusantara. Bagi Mujamil Qomar, Islam Nusantara merupakan model pemikiran, pemahaman dan pengamalan ajaran-ajaran Islam melalui pendekatan kultural, sehingga mencerminkan identitas Islam yang bernuansa metodologis. Islam Nusantara ini merefleksikan pemikiran, pemahaman, dan pengamalan Islam yang moderat, inklusif, toleran, cinta damai, menyejukkan, mengayomi dan 
menghargai keberagaman (kebinekaan). ${ }^{1}$ Oleh karenanya, Islam Nusantara bukanlah bentuk agama baru, melainkan sebuah tipologi dan metodologi (manhaj) keagamaan yang kesemuanya tetap dalam bingkai agama Islam. Seperti yang ditegaskan Said Aqil Siradj bahwa Islam Nusantara bukanlah sekte atau aliran baru dan tidak dimaksudkan untuk mengubah doktrin Islam. Menurutnya, Islam Nusantara adalah pemikiran yang berlandaskan pada sejarah Islam yang masuk ke Indonesia yang tidak melalui peperangan, tetapi melalui kompromi terhadap budaya. ${ }^{2}$

Dalam pengertian lain, menarik kiranya apa yang diklasifikasikan oleh Khabibi Muhammad Luthfi terkait Islam Nusantara dengan mengaca pada pendekatan yang digunakan oleh para intelektual NU. Menurutnya, dalam mengonsep Islam Nusantara, intelektual NU menggunakan delapan pendekatan, yaitu filsafat, budaya, linguistik, filsafat hukum, hukum, historis antropologis, historisfilologi dan sosiologis-antropologis-historis. ${ }^{3}$

Di antara delapan pendekatan tersebut, disini akan menampilkan pendekatan filofosif saja karena dianggap relevan dengan pengembangan kajian tentang pendidikan Islam Nusantara. Islam Nusantara, seperti diungkapkan Isom Yusqi (nu.or.id), diposisikan sebagai salah satu pendekatan dalam mengkaji Islam yang akan melahirkan berbagai displin ilmu, seperti fikih nusantara, siyasah nusantara, muamalah nusantara, qanun nusantara, perbankan Islam nusantara, ekonomi Islam nusantara, dan berbagai cabang ilmu Islam lain atas dasar sosio-episteme ke-nusantara-an. ${ }^{4}$

IN sebagai pendekatan keilmuan akan melahirkan varian fokus kajian yang sesuai dengan disiplin keilmuan. Ini menarik karena disiplin keilmuan Islam juga bergerak searah dengan tipologi keislaman khas Nusantara. Jika IN sebagai sebuah pendekatan, baik secara filosofis maupun kultural, tentu saja IN dengan segala

${ }^{1}$ Mujamil Qomar, "Islam Nusantara: Sebuah Alternatif Model Pemikiran, Pemahaman, dan Pengamalan Islam", dalam el Harakah Vol.17 No.2 Tahun 2015

2 Ahmad Sahal, "Prolog: Kenapa Islam Nusantara", dalam Akhmad Sahal (ed.), Islam Nusantara: Dari Ushul Figh Hingga Paham Kebangsaan, (Bandung: Mizan, 2015), hlm. 15

${ }^{3}$ Khabibi Muhammad Luthfi , "Islam Nusantara: Relasi Islam dan Budaya Lokal," dalam Jurnal Shahih, Vol. 1, Nomor 1, Januari-Juni 2016 ISSN: 2527-8118 (p); 2527-8126 (e) LP2M IAIN Surakarta

${ }^{4} \mathrm{Ibid}$, 
derivasi keilmuan Islam juga memiliki karakteristik yang berbeda. Ini yang perlu dikembangkan sebagai bahan kajian.

Begitu juga tidak berlebihan jika pendidikan Islam di Nusantara secara tidak langsung juga menampilkan pendidikan Islam berwawasan Nusantara. Secara teoritis dan praktis, pendidikan Islam yang dikembangkan di Nusantara tidak bisa dilepaskan dari jalinan kontak dengan berbagai unsur keislaman dan kenusantaraan yang tumbuh dan berkembang di Nusantara, sehingga pendidikan Islam yang dikonsepsikan, tidak akan terlepas dari jejak historis tersebut. Maka, dalam pemahaman ini, kita perlu memposisikan bagaimana perspektif Islam Nusantara turut mewarnai konsep dan praktik pendidikan Islam.

\section{Persentuhan Islam Nusantara dan Pendidikan Islam}

Pendidikan Islam di Nusantara tidak bisa dilepaskan dari asalusul penyebaran Islam di Nusantara. Ini yang membedakan antara pendidikan Islam sebagai konsep yang benar-benar baru, dengan pendidikan Islam sebagai dampak lanjutan dari proses penyebaran Islam. Dengan melihat perkembangan pendidikan Islam yang ada, bisa diketahui bahwa pendidikan Islam adalah salah satu strategi kebudayaan Islam seiring dengan dinamika Islam yang terjadi di Nusantara.

Gerak perkembangan dakwah Islam yang disertai dengan pendirian lembaga pendidikan Islam adalah satu tipologi yang tidak hanya berciri khas Islam Nusantara tetapi juga sebagai jawaban paling efektif untuk menanamkan nilai-nilai Islam dari generasi ke generasi. Pendidikan Islam dengan berbagai persentuhan di dalamnya, adalah pengembangan masyarakat Islam yang lebih sistematis disamping strategi non-formal dan informal seperti pengajian umum dan majlis ta'lim. Meski pada awal-awal penyebaran Islam pendidikan Islam sangat bersentuhan dengan dakwah Islam, namun secara fokus kajian, pendidikan Islam ditempatkan sebagai proses pengembangan kompetensi keagamaan yang sistematis.

Dari sini kita bisa melihat bagaimana persentuhan Islam Nusantara dengan pendidikan Islam di Nusantara. Persentuhan 
ini akan melahirkan bagaimana corak pendidikan Islam yang terbangun di kawasan Nusantara. Jika Islam Nusantara dipahami sebagai tipologi keislaman di Nusantara, maka pendidikan Islam di Nusantara juga merupakan tipologi pendidikan Islam yang khas Nusantara. Ini cukup beralasan karena beberapa hal. Pertama, pendidikan Islam di Nusantara memiliki perbedaan dengan pendidikan Islam di beberapa Negara lain. Hal ini bisa dilihat dari unsur kebudayaan yang melekat pada nomenklatur, pendirian, dan pelaksanaan pendidikan Islam, baik dalam bentuk surau (di Minangkabau), pesantren (di Jawa), madrasah dalam bentuknya yang terkini.

Diantara yang melekat adalah metode sorogan, bandongan, arab pegon (jawi), dan lainnya. Kekhasannya lagi adalah adanya struktur kepemimpinan yang terdiri dari kyai dan keunikan model kepemimpinan di dalamnya. Bahkan, kepemimpinan Kyai ini barangkali tidak ditemukan di beberapa belahan dunia. Ini menandakan bahwa pendidikan Islam sebagai kelanjutan dari Islam Nusantara yang telah menjalin kontak dengan berbagai unsur budaya yang ada di Nusantara.

Kedua, meski pendidikan Islam dibenturkan dengan konsep pendidikan liberal di awal-awal perkembangan Modern, pada prinsipnya pendidikan Islam tidak menampilkan pendidikan yang sepenuhnya liberal, dan bahkan cenderung menampilkan format yang berbeda. Dalam konten kurikulum, misalnya, ia tidak sepenuhnya kruikulum pendidikan modern, melainkan adanya interaksi dan akulturasi dengan unsur budaya lokal.

\section{Pendidikan Islam dalam Perspektif Islam Nusantara}

Melihat dinamika pesentuhan pendidikan Islam dengan perspektif Islam Nusantara, kita sebenarnya bisa merumuskan beberapa karakteristik yang melekat dalam dunia pendidikan Islam di Nusantara. Setidaknya kita bisa melihat pada dua hal.

\section{Orientasi Pendidikan}

a. Berorientasi Ilahiyah

Orientasi pendidikan Islam nusantara cenderung menempatkan orientasi ilahiyah pada orientasi pertama. Orientasi ini bukan 
dimaksudkan sebagai orientasi yang terlalu melangit dan sulit ditemukan indikator keberhasilannya, melainkan justru orientasi ini menjadi ruh utama dan spirit bagi segala aktivitas pendidikan Islam. Dalam perspektif Islam Nusantara, pendidikan berorientasi ilahiyah berarti menempatkan Tuhan dalam puncak tujuan dari segala aktivitas pendidikan. Pendidikan Islam adalah pendidikan yang mengandaikan adanya hubungan yang baik antara manusia dengan Tuhan. Ini sejalan dengan karakter penyebaran Islam yang dimulai dengan pengenalan ajaran Tauhid. Bahkan, di beberapa pesantren dan madrasah, misalnya, kajian-kajian tentang tauhid menampati posisi yang penting.

Melalui proses historis ini, Pancasila merupakan salah satu landasan penting yang menempatkan Ketuhanan Yang Maha Esa sebagai sila pertama. Ini menandakan bahwa dasar pendidikan Islam juga memiliki relevansi dengan ideologi kebangsaan. Maka, dengan jelas bahwa orientasi penting pendidikan Islam nusantara adalah konsep ketuhanan, sebagai basis dalam mengajarkan hubungan vertikal antara manusia dengan Tuhannya.

\section{b. Berorientasi Insaniyah}

Orientasi kedua ini sebagai tindak lanjut dari orientasi pertama. Bukan berarti yang kedua harus dinomorduakan, melainkan justru bagian integral dalam segala hubungan manusia. Sebagai tindak lanjut, kesuksesan dalam menghamba kepada Tuhan, berarti juga kesuksesan di dalam menjalin hubungan antar manusia. Jika orientasi pendidikan Insaniyah buruk, maka secara otomatis mengindikasikan buruknya orientasi ilahiyah. Bahkan tidak sempurna kualitas seseorang jika hanya mementingkan komunikasi vertikal, tanpa memperbaiki komunikasi yang bersifat horizontal.

Nilai Insaniyah di sini merupakan nilai yang perlu diterapkan oleh manusia dalam hubungannya dengan interaksi antar sesama. Ini merupakan keniscayaan hidup bahwa manusia adalah makhluk sosial, yang berarti manusia tidak bisa lepas dari interaksi atau hubungan antar sesama.

Konsep ini bisa kita lihat dari kecenderungan perumusan pendidikan Islam yang menempatkan kemasalahatan manusia 
sebagai indikator keberhasilan bagi pendidikan Islam. Dalam beberapa kajian terkait pendidikan Islam, juga dikenal doktrin bahwa sebaik-baik manusia adalah yang bermanfaat bagi manusia lainnya. Ini menandakan adanya penekanan pada orientasi insaniyah yang menjadikan pendidikan Islam tidak hanya melangit, tetapi juga membumi.

c. Berorientasi 'Alamiyah

Islam tidak hanya berbicara soal ritual ubudiyah formal keseharian, melainkan juga berbicara mengenai aspek yang sekarang ini menjadi kegelisahaan warga dunia, yakni lingkungan hidup. Krisis lingkungan hidup mengajak agama untuk dicarikan legitimasinya sebagai basis teologis perumusan kesadaran lingkungan, atau yang dikenal dengan ecotheology. Dalam hal ini Islam dianggap menyumbangkan nilai untuk mengatasi masalah krisis lingkungan.

Kenyataan ini ditunjukkan oleh hadirnya beberapa pemikir Islam untuk mencari formulasi/rumusan yang tepat mengenai persoalan lingkungan hidup. Seyyed Hossein Nasr, misalnya, banyak menulis karya-karya tentang isu lingkungan dari sudut pandang tradisionalis atau sufi. Dalam karya pertamanya, The Encounter of Man and Nature: The Spiritual Crisis of Modern Man, ${ }^{5}$ Nasr memprediksikan konsekuensi-konsekuensi berbahaya yang mungkin timbul dari krisis yang terjadi pada lingkungan.

Buku tersebut juga merupakan kritik filosofis terhadap konsepsi modern tentang alam sebagai sebuah materi yang dapat dikuasai dan dikendalikan oleh ilmu pengetahuan dan teknologi modern. Ini juga merupakan karya pertama Nasr dimana ia menantang ilmu pengetahuan modern dan pandangan-pandangan sekulernya. Dalam bukunya yang lain, Religion and the Order of Nature, ${ }^{6}$ Nasr memberikan sebuah analisa tentang munculnya ilmu pengetahuan modern di satu sisi, dan kritik filsafat-filsafat sekular dan reduksionis berkenaan dengan alam, disisi lain. Buku ini juga

5 Seyyed Hossein Nasr, The Encounter of Man and Nature: The Spiritual Crisis of Modern Man, London: Allen and Unwin, 1968, diterjemahkan ke dalam bahasa Indonesia oleh Ali Noer Zaman, Antara Tuhan, Manusia dan Alam: Jembatan Filosofis dan Religius Menuju Puncak Spiritual, Yogyakarta: IRCiSoD, 2003

'Seyyed Hossein Nasr, Religion and the Order of Nature, New York: Oxford University Press, 1996 
berusaha untuk menghidupkan kembali ide sakral tentang alam dan kosmologi tradisional yang menjadi minat Nasr sepanjang karir intelektualnya.

Ternyata, dalam kajian pendidikan Islam yang banyak mengkaji pemikir pemikir klasik seperti Al-Ghazali juga menekankan aspek ini. Ia memandang bahwa semua ilmu harus berorientasikan pada pencapaian spiritualitas yang tinggi. Ilmu alam, misalnya, harus dijadikan sebagai proses bertafakkur (merenung) untuk mengenali tanda-tanda kebesaran Tuhan dan mengambil hikmah dari setiap gejala alam. ${ }^{7}$ Tafakkur dalam pengertian ini diartikan dengan membaca realitas dalam dimensi wawasan spiritual dan penguasaan pengetahuan hikmah. Al-Ghazali juga menegaskan bahwa ilmuilmu keagamaan hanya dapat diperoleh dengan kesempurnaan rasio dan kejernihan akal budi. Karena, hanya dengan rasiolah manusia mampu menerima amanat dari Allah dan mendekatkan diri kepada-Nya.

Ini mengandung pengertian bahwa orientasi ilahiyah pada dasarnya mengandung konsekuensi kepedulian manusia terhadap alam semesta yang merupakan bagian dari tanda-tanda kebesaran Tuhan. Oleh karenanya, dalam pendidikan Islam yang berkembang di Nusantara, juga banyak ditemukan dalil-dalil yang menekankan pentingnya menjalin hubungan harmonis dengan alam semesta.

\section{Corak Pendidikan}

a. Pendidikan Integratif

Islam nusantara juga menemukan bentuknya dalam model pendidikan islam yang integratif. Dalam pengembangan kurikulum, misalnya, integrasi ini banyak dibicarakan oleh para ilmuwan muslim seperti Fazlur Rahman, Seyyed Hossein Nasr, Ismail Raji al-Faruqi, dan Syekh Muhammad Naquib al-Attas. Di Indonesia upaya integrasi ilmu juga dikembangkan oleh ilmuwan muslim seperti Kuntowijoyo dengan konsep “Pengilmuan Islam," dengan menjadikan al-Qur'an sebagai paradigma keilmuan, yang dalam

\footnotetext{
${ }^{7}$ Pemikiran al-Ghazali tentang perenungan terhadap alam semesta bisa dilihat dalam bukunya, al-Hikmah fi al-Makhluqatillah, $\mathrm{tt}$ 
hal ini bisa dilakukan dengan dua cara, yaitu: (1) integralisasi yaitu pengintegrasian kekayaan keilmuan manusia dengan wahyu; (2) objektifikasi yaitu menjadikan pengilmuan Islam sebagai rahmat untuk semua orang. ${ }^{8}$ Imam Suprayogo menawarkan integrasi ini dengan mengilustrasikan sebatang pohon yang utuh, dimana kajian keagamaan harus ditopang dengan landasan keilmuan yang lain agar studi-studi keislaman bisa berdiri kokoh. ${ }^{9}$ Integrasi tersebut dalam pandangan Amin Abdullah perlu dipadukan dengan interkoneksi. Pendekatan integratif-interkonektif adalah pendekatan yang berusaha saling menghargai, dalam arti keilmuan umum dan agama sadar akan keterbatasan masingmasing dalam memecahkan persoalan manusia. Hal ini akan melahirkan sebuah kerja sama setidaknya saling memahami pendekatan (approach) dan metode berpikir (process and procedure) antara kedua kelimuan tersebut. ${ }^{10}$ Prinsip integarasi yang ditawarkan para pemikir di atas setidaknya bisa mengembalikan spirit Islam Nusantara dalam perumusan kebijakan pendidikan Islam.

\section{b. Pendidikan Berbasis Karakter}

Hancurnya peradaban bangsa-bangsa yang pernah ada dalam sejarah selalu berkaitan dengan merosotnya moral, adab, dan atau karakter. Dalam menilai peradaban Islam, Al-Attas membuat pernyataan bahwa akar kemunduran Islam adalah the lost of adab (hilangnya adab). Hilangnya adab membuahkan kesalahpahaman dan kekeliruan dalam ilmu. ${ }^{11}$ Persoalan adab atau akhlak ini merupakan poin terpenting dalam rumusan Islam Nusantara.

Jika melihat dinamika pendidikan Islam di Nusantara, pendidikan berbasis karakter cenderung menjadi model yang sangat ditekankan. Salah satu bukti bahwa model keislaman berikut

8 Kuntowijoyo, Islam sebagai Ilmu: Epistemologi, Metodologi dan Etika (Yogyakarta: Teraju, 2004), 49

${ }^{9}$ Imam Suprayogo, Paradigma Pengembangan Keilmuan pada Perguruan Tinggi: Konsep Pendidikan Tinggi yang Dikembangkan UIN Malang (Malang: UIN Malang Press, 2005)

10 Abdullah, Amin. "Desain Pengembangan Akademik IAIN menuju UIN Sunan Kalijaga: dari penekatan Dikotomis-Atomistis ke arah integratif-interdisiplinary" dalam Zainal Abidin Bagir, Integrasi Ilmu dan Agama, (Yogyakarta: Pustaka Pelajar, 2008), 242

11 Syed Muhammad Naquid Al-attas, Islam dan Sekularisme, ter. Khalif Muammar, (Bandung: PIMPIN, 2011) hal. 129 
kelembagaan pendidikannya tidak berusaha mereduksi karakter Islam dan kenusantaraannya. Baik tokoh-tokoh pahlawan maupun para Kyai tetap memegang teguh konsep character building dalam memandang persoalan pendidikan.

\section{c. Pendidikan Berwawasan Multikultural}

Perjumpaan Islam dengan berbagai berbagai kultur dan berjalan harmoni di bumi Nusantara menunjukkan adanya respek yang tinggi terhadap keragaman. Secara konseptual, seorang Kiai Tholhah Hasan mencoba merumuskan pendidikan Islam multikultural. Menurutnya, pendidikan Islam multikultural adalah pendidikan yang menempatkan multikulturalisme sebagai salah satu visi pendidikan, dengan karakter utama inklusif, egaliter, demokratis, dan humanis, namun tetap kokoh pada nilai-nilai spiritual dan keyakinan yang berdasarkan al-Qur'an dan al-Hadist. ${ }^{12}$ Dalam hal ini, pendidikan Islam multikultural memiliki ciri khas di dalam menempatka multikulturalisme sebagai visi pendidikan. Ciri khas tersebut terletak pada nilai-nilainya yang digali dari doktrin, fakta historis dan dinamika intelektual umat Islam sebagai perwujudan dari ajaran yang terkandung al-Qur'an dan al-Hadist.

Berdasarkan kajian Tholhah Hasan, ${ }^{13}$ dalam kajian-kajian keaswajaan atau keislaman inklusif, terdapat akar-akar nilai inklusif yang mendorong terwujudnya budaya multikulturalis. Akar-akar nilai inklusif ini merupakan sekumpulan doktrin, fakta historis, dan dinamika kultural Islam, sejak zaman Rasulullah SAW sampai sekarang, yang memudahkan Islam sebagai agama yang mempunyai "karakter inklusif". Diantara nilai inklusif tersebut diantaranya Ta'aruf (saling mengenal), At-Tawassuth (Moderat), At-Tasamuh (Toleran), At-Ta'awun (Tolong Menolong), At-Tawazun (Harmoni), dan At-Tasyawur (Dialog).

\section{d. Pendidikan Bercorak Sufistik}

Dalam Rakernas LESBUMI PBNU pada Rabu-Kamis, 27 dan 28 Januari 2016 di Gedung PBNU, menghasilkan tujuh strategi

${ }^{12}$ Muhammad Tholhah Hasan, Pendidikan Multikultural Sebagai Opsi Penanggulangan radikalisme (Malang: Lembaga Penerbitan UNISMA, 2016) Cet. Ke-3, hlm. 51

${ }^{13}$ Muhammad Tholhah Hasan, Pendidikan Multikultural, hlm. 60-72 
kebudayaan atau Saptawikrama (Al Qowaid As Sabah). Isi dari tujuh strategi tersebut adalah: 1) Menghimpun dan mengonsolidasi gerakan yang berbasis adat istiadat, tradisi dan budaya Nusantara; 2) Mengembangkan model pendidikan sufistik (tarbiyah wa ta'lim) yang berkaitan erat dengan realitas di tiap satuan pendidikan, terutama yang dikelola lembaga pendidikan formal (ma'arif) dan Rabithah Ma'ahid Islamiyah (RMI); 3) Membangun wacana independen dalam memaknai kearifan lokal dan budaya Islam Nusantara secara ontologis dan epistemologis keilmuan; 4) Menggalang kekuatan bersama sebagai anak bangsa yang bercirikan Bhinneka Tunggal Ika untuk merajut kembali peradaban Maritim Nusantara; 5) Menghidupkan kembali seni budaya yang beragam dalam ranah Bhnineka Tunggal Ika berdasarkan nilai kerukunan, kedamaian, toleransi, empati, gotong royong, dan keunggulan dalam seni, budaya dan ilmu pengetahuan; 6) Memanfaatkan teknologi informasi dan komunikasi untuk mengembangkan gerakan Islam Nusantara; 7) Mengutamakan prinsip juang berdikari sebagai identitas bangsa untuk menghadapi tantangan global.

Meski tujuh strategi kebudayaan di atas menyangkut keislaman nusantara secara umum, ada satu strategi khusus yang berkaitan dengan pendidikan Islam yang terdapat pada poin kedua, yakni mengembangkan model pendidikan sufistik (tarbiyah wa ta'lim) yang brkaitan erat dengan realitas di tiap satuan pendidikan, terutama yang dikelola lembaga formal (ma'arif) dan Rabithah Ma'ahid Islamiyah (RMI). Poin ini bukan tanpa alasan karena secara historis, keislaman yang menekankan pada wilayah bathin (esoterisme) lebih menghadirkan Islam subtantif. ${ }^{14}$ Islam subtantif tidak mudah terjebak pada sikap ekstrimisme, dan sebagai ciri khasnya ia sangat lentur dan terbuka dalam menjalin kontak sosial-budaya yang ada.

Pendidikan dengan corak sufistik mengedepankan pada nilainilai sufistik yang kaya dengan nilai kearifan. Pendidikan sufistik juga menawarkan formulasi pendidikan yang mengajarkan pada

${ }^{14}$ Istilah Islam Subtantif bukan hal baru, namun cukup popular dan apik berkat penjelasan Azyumardi Azra. Menurutnya jika Islam ingin berperan lebih luas, maka harus mengedepankan pesan-pesan moral, bukan mengedepankan symbol. Azyumardi Azra, Islam Subtantif: Agar Umat Tidak Menjadi Buih (Bandung: Mizan, 2000) hlm. 138 
keterbukaan terhadap perbedaan. Bahkan, banyak sekali ajaranajaran sufistik yang mendorong terwujudnya masyarakat toleran. Watak toleransi sufi ini juga dijelaskan secara baik oleh sejarawan, Marshal Hodgson dalam bukunya The Ventur of Islam bahwa umumnya, kaum Sufi cenderung toleran terhadap perbedaanperbedaan lokal, meskipun ulama syari'at cenderung tidak toleran. Ulama-ulama harus berkonsentrasi pada masalah-masalah kesesuaian lahiriah, sebagaimana diperintahkan oleh syariat, dalam upaya menjaga kerangka hukum dan institusi demi kesatuan sosial. Sebaliknya, bagi para Sufi, hal-hal lahiriah dinomorduakan. Bagi kebanyakan mereka, terutama pada periode pertengahan Awal, bahkan perbedaan antara Islam dan tradisitradisi kultural lain seperti Kristen bersifat sekunder; demikian juga beragam perbedaan dalam adat istiadat kebiasaan sosial di kalangan umat Muhammad. Yang penting bagi mereka adalah kecondongan ruhani kalbu kepada Tuhan. ${ }^{15}$

Watak kaum sufi yang lebih mendahulukan aspek keruhanian dalam mendekati Tuhan perlu menjadi renungan bagi kaum beragama di tengah perbedaan yang ada. Yang diutamakan dalam kehidupan beragama bukan lah keegoisan dalam meyuarakan panji-panji agama di ruang publik, melainkan keikhlasan dalam meraih ridha Tuhan. Batas-batas agama, ras, budaya, politik, dan ideologi yang seringkali melahirkan sikap intoleransi setidaknya bisa ditembus dengan meneladani watak sufistik yang cenderung toleran.

Ajaran sufistik juga menawarkan konsep pendidikan multikultural berbasis afektif, dengan karakteristik pada pengembangan paradigma keberagaman yang inklusif, pengembangan kesadaran untuk belajar hidup dalam perbedaan. ${ }^{16}$ Diantara inspirasi tasawuf dalam pendidikan multikultural ditunjukkan oleh Said Aqil Siraj yang mengatakan bahwa dalam tasawuf, IQ (dzaka 'aqli), EQ (dzaka dzihni), dan SQ (dzaka qalbi) merupakan komponen yang perlu dikembangkan secara harmonis sehingga menghasilkan daya

${ }^{15}$ Marshall G.S. Hodgson, The Venture of Islam, terj. (Jakarta: Paramadina, 2002) hlm. 217

16 Alivermana Wiguna, Isu-isu Kontemporer Pendidikan Islam (Yogyakarta:Deepublish, 2014), hlm. 194-195 
guna yang luar biasa baik secara horizontal maupun vertikal. Pada prinsipnya manusia perlu dikembalikan pada "pusat eksistensi" (markaz al-wujud) atau "pusat spiritual" dan dijauhkan dari "hidup di pinggir lingkar eksistensi. Di tengah kondisi multikultural, sekiranya patut dipertahankan dan dikembangkan adalah penguatan pendidikan yang berbaiskan spiritulitas yang justru akan meneguhkan autentisitas kemanusiaan yang senantiasa dicitrai oleh esensi ketuhanan. ${ }^{17}$

Seyyed Hossein Nasr sendiri, lewat karyanya Knowledge and the Sacred, memaparkan wacana-wacana metafisik yang mempertemukan agama-agama dan tradisi spiritual yang otentik pada satu titik kesatuan transenden. Yakni, Tuhan yang dicari (umat ber-agama) melalui beragam agama (sebagai jalan-jalan menuju Tuhan). Inilah inti dasar perspektif filsafat perennial. Bila disebut perennial religion (agama dan atau tradisi perennial), maksudnya adalah ada hakikat yang sama dalam setiap agama. Rumusan filosofisnya: the heart of religion or the religion of heart. ${ }^{18}$ Ini bukan berarti mengaburkan religiusitas seseorang, melainkan untuk menegaskan diri bahwa manusia dalam pergumulannya senantiasa mencapai yang pusat (Tuhan). Mempusatkan Tuhan berarti juga tidak terlalu mempermasalahkan adanya perbedaan.

Seorang sufi terkenal, Ibn 'Arabi, lebih tegas lagi menyebut Tuhan yang dipercayai manusia atau "Tuhan kepercayaan" adalah gambar atau bentuk Tuhan, atau pemikiran, konsep, ide, atau gagasan tentang Tuhan yang dicipta-kan oleh akal manusia atau taklidnya. Tuhan seperti itu bukan lah Tuhan se bagaimana Dia sebenarnya, Tuhan pada diri-Nya, zat-Nya, tetapi adalah Tuhan yang diciptakan oleh manusia sesuai dengan kemampuan, pengetahuan, penangkapan, dan persepsinya.

Dengan mengutip perkataan al-Junayd, Ibn 'Arabi berkata, "Warna air adalah warna bejana yang ditempatinya" (Lawn al-ma' lawn ina'ih). Itulah sebabnya mengapa Tuhan melalui sebuah hadis qudsi ber kata, "Aku adalah dalam sangkaan hamba-Ku tentang

\footnotetext{
${ }^{17}$ Saiq Aqil Siraj, Tasawuf Sebagai Kritik Sosial (Bandung: Mizan, 2006) hlm. 240

${ }^{18}$ Seyyed Hossein Nasr, Knowledge and the Sacred (New York: State University of New York Press, 1989), hlm 91.
} 
Aku' (Ana 'inda zhann 'abdi bi). ${ }^{19}$ Tuhan disangka, bukan diketahui. Dengan kata lain, Tuhan hanya dalam sangkaan manusia, bukan dalam pengetahuannya.

Ajaran sufistik yang cenderung berawawasan multiklutural tersebut sejalan dengan apa yang dilakukan oleh para guru sufi dalam menyebarkan agama Islam melalui pendidikan informal. Dengan kesantunan, kelenturan, dan kearifan, para guru sufi mampu merangkul berbagai lapisan masyarakat untuk menerima Islam. Tanpa ajaran-ajaran sufistik, kemungkinan penyebaran Islam atau bahkan pendidikan Islam di Nusantara akan berbuah penolakan di masyarakat.

\section{Penutup}

Pendidikan Islam nusantara tidak bisa dilepaskan dari dinamika perkembangan Islam di Nusantara. Sejak Islam hadir di nusantara, pendidikan Islam sebenarnya sudah menampilkan bentuknya meski masih sangat sederhana. Tentu saja di dalamnya mengalami pergeseran, perubahan, dan inovasi yang sampai saat ini masih terus berjalan.

Apa yang dikaji dalam tulisan di atas merupakan upaya mempertemukan - sekaligus juga merumuskan - pendidikan Islam di nusantara dengan karakter keislaman dan kenusantaraan. Dengan menitikberatkan pada orientasi dan corak pendidikan, setidaknya bisa mendeskripsikan bagaimana konsep pendidikan Islam dalam bingkai Islam Nusantara.

Pembahasan dengan fokus kajian di atas juga bermaksud memancing, menstimulasi, dan mendorong diskusi dan riset lebih jauh lagi. Dorongan ini cukup beralasan mengingat potensi besar keberadaan pendidikan Islam nusantara dalam menjawab tantangan global, terutama dalam melahirkan sikap keagamaan dan sikap sosial generasi terdidik. Pada akhirnya, pendidikan Islam Nusantara menjadi rujukan pendidikan moderat.

${ }^{19} \mathrm{Ibn}$ 'Arabi, Fushus al-Hikam (Beirut: Dar al-Kitab al-'Arabi, 1980), 225-226 


\section{Daftar Pustaka}

'Arabi, Ibn. Fushus al-Hikam. Beirut: Dar al-Kitab al-'Arabi, 1980.

Al-attas, Syed Muhammad Naquid Islam dan Sekularisme, ter. Khalif Muammar. Bandung: PIMPIN, 2011.

Azra, Azyumardi. Islam Subtantif: Agar Umat Tidak Menjadi Buih. Bandung: Mizan, 2000.

Buku Statistik Pendidikan Islam Tahun Pelajaran 2011/2012

Buku Statistik Pendidikan Islam Tahun Pelajaran 2014/2015

Hasan, Muhammad Tholhah Pendidikan Multikultural Sebagai Opsi Penanggulangan radikalisme. Malang: Lembaga Penerbitan UNISMA, 2016. Cet. Ke-3.

Hodgson, Marshall G.S. The Venture of Islam, terj. Jakarta: Paramadina, 2002.

Ibn 'Arabi, Fushus al-Hikam. Beirut: Dar al-Kitab al-'Arabi, 1980.

Luthfi, Khabibi Muhammad "Islam Nusantara: Relasi Islam dan Budaya Lokal," dalam Jurnal Shahih, Vol. 1, Nomor 1, Januari-Juni 2016 ISSN: 2527-8118 (p); 2527-8126 (e) LP2M IAIN Surakarta

Nasr, Seyyed Hossein, Knowledge and the Sacred. New York: State University of New York Press, 1989.

Nasr, Seyyed Hossein, The Encounter of Man and Nature: The Spiritual Crisis of Modern Man, London: Allen and Unwin, 1968, diterjemahkan ke dalam bahasa Indonesia oleh Ali Noer Zaman, Antara Tuhan, Manusia dan Alam: Jembatan Filosofis dan Religius Menuju Puncak Spiritual, Yogyakarta: IRCiSoD, 2003.

Nasr, Seyyed Hossein. Religion and the Order of Nature. New York: Oxford University Press, 1996.

Qomar, Mujamil "Islam Nusantara: Sebuah Alternatif Model Pemikiran, Pemahaman, dan Pengamalan Islam", dalam el Harakah Vol.17 No.2 Tahun 2015

Sahal, Ahmad "Prolog: Kenapa Islam Nusantara", dalam Akhmad Sahal (ed.), Islam Nusantara: Dari Ushul Figh Hingga Paham Kebangsaan. Bandung: Mizan, 2015.

Siraj, Saiq Aqil. Tasawuf Sebagai Kritik Sosial. Bandung: Mizan, 2006. 
Wiguna, Alivermana. Isu-isu Kontemporer Pendidikan Islam. Yogyakarta:Deepublish, 2014.

Yunasril Ali, Sufisme dan pluralisme: Memahami Hakikat Agama dan Relasi Agama-agama. Jakarta: PT Elex Media Komputindo, 2012. 